\title{
YTHDF2 wt Allele
}

National Cancer Institute

\section{Source}

National Cancer Institute. YTHDF2 wt Allele. NCI Thesaurus. Code C98000.

Human YTHDF2 wild-type allele is located in the vicinity of 1 p35 and is approximately 33 $\mathrm{kb}$ in length. This allele, which encodes YTH domain family protein 2, may play a role in both humoral immunity and signal transduction. A translocation involving this gene and the RUNX1 gene may be associated with acute myeloid leukemia. 